\title{
PENGEMBANGAN DAN VALIDASI KUESIONER PENGETAHUAN MAHASISWA FARMASI TERKAIT PRODUK KEFARMASIAN SERTA ALAT KESEHATAN DALAM PENCEGAHAN COVID-19
}

\section{DEVELOPMENT AND VALIDATION OF QUESTIONNAIRE ABOUT KNOWLEDGE ON PHARMACEUTICAL PRODUCT AND MEDICAL DEVICES AS PREVENTIVE MEASURES TOWARDS COVID-19 AMONG PHARMACY STUDENTS}

\author{
Iman Surya Pratama*, Siti Rahmatul Aini, Lalu Husnul Hidayat, Muhammad Hipzul Mursyid, dan \\ Sri Ulan Muharromi \\ Program Studi Farmasi Fakultas Kedokteran Universitas Mataram, Mataram, Indonesia \\ *Email: imanespe@unram.ac.id
}

Diterima: 8 Januari 2021. Disetujui: 17 Februari 2021. Dipublikasikan: 3 Maret 2021

\begin{abstract}
Abstrak: Asesmen pengetahuan tentang penggunaan produk kefarmasian dan alat kesehatan penting dilakukan pada mahasiswa farmasi sebagai dasar upaya pencegahan COVID-19. Kuesioner yang valid dan reliabel dibutuhkan dalam asesmen tersebut, namun studi di Indonesia masih terbatas. Oleh karena itu, studi ini bertujuan untuk menguji validitas dan reliabilitas hasil pengembangan kuesioner gambaran pengetahuan pengetahuan mahasiswa terkait penggunaan produk kefarmasian dan alat kesehatan dalam upaya preventif Covid-19. Penelitian ini bersifat deskriptif. Uji validitas konten melibatkan penilaian 6 orang pakar secara kualitatif (kesepakatan pakar) dan kuantitatif (indeks dan rasio validitas). Validitas muka dilakukan pada 30 orang mahasiswa secara kualitatif. Uji validitas konstruk dan reliabilitas dilakukan pada 30 orang mahasiswa dengan pendekatan korelasi bivariat dan Cronbach Alpha. Hasil uji validitas isi diperoleh kesepakatan pakar pada 55 item yang telah dikembangkan. Adapun secara kuantitatif nilai ICV-I sebesar 0,8 (1 item) dan 1. CVR bernilai 1 kecuali pada 1 item sebesar 0,6. Secara kuantitatif diperoleh 54 item pertanyaan yang valid. Validitas muka dinyatakan lolos setelah satu kali revisi. Pada uji validitas konstruk dan reliabilitas diperoleh nilai Chronbach Alpha 0.881 dan korelasi item terkoreksi kurang dari 0.3 pada 14 item. Berdasarkan hasil uji diperoleh kuesioner yang valid dan reliabel untuk mengukur pengetahuan tentang penggunaan produk kefarmasian dan alat kesehatan pada mahasiswa sebagai upaya preventif Covid-19.
\end{abstract}

Kata Kunci: Validasi, Kuesioner, Pengetahuan, Produk Kefarmasian dan Alat Kesehatan, Preventif Covid-19

\begin{abstract}
The knowledge assessment about pharmaceutical product and medical instruments is important to do with pharmacy's students as the basic in preventing COVID-19. Valid and reliable questionnaire were needed in that assessment, nevertheless study in Indonesia is still being limited. In consequence, this study objectives were to examine validity and realibility of questionnaire development outcome as student's knowledge description related to the use of pharmaceutical product and medical instruments in COVID-19 preventive actions. This research was a descriptive study. Content validity test involved evaluation out of 6 experts qualitatively (expert's agreement) and quantitatively (index and ratio of validity). Face validity was done to 30 students qualitatively. Construct test of validity and reliability were done to 30 students by using bivariate correlation and Cronbach Alpha. The outcome of content validity test was obtained expert's agreement for 55 items that has developed. While quantitatively, ICV-I value was 0,8 (1 item) and 1. CVR's value was 1 excluded for 1 item in the amount of 0,6. Qualitatively, there were 54 items of question were being valid. Face validity was passed after once revision. For the construct test of validity and reliability, Cronbach Alpha's value was 0.881 and item's correlation being corrected less than 0.3 in 14 items. Based on test result, valid and reliable questioners to measure knowledge about the use of pharmaceutical products and medical instruments have been obtained towards student as preventive action to COVID-19.
\end{abstract}

Keywords: Validation, Questionnaire, Knowledge, Pharmaceutical Product and Medical Device, Preventive Measures Covid-19

\section{PENDAHULUAN}

Covid-19 merupakan penyakit yang diakibatkan oleh galur ketujuh virus korona dan telah dinyatakan menjadi pandemik sejak 11 Maret 2020 [1]. Provinsi Nusa Tenggara Barat (NTB) hingga 21 November 2020 telah diperoleh 4.594 kasus dengan
574 orang dalam perawatan, 3775 orang sembuh dan 245 orang meninggal dunia [2].

Upaya promotif-preventif seperti peningkatan komunikasi, informasi, edukasi merupakan bagian penting dalam penanggulangan Covid-19 sebagaimana Keputusan Menteri Kesehatan No. HK. 
01.07/MENKES/104/2020. Upaya ini dilakukan melibatkan seluruh pihak termasuk mahasiswa farmasi di tingkat sarjana.

Selain amanat sebagai Duta Perubahan Perilaku COVID-19 [3], kompetensi lulusan sarjana farmasi menuntut mahasiswa mampu mencari, menyiapkan dan memberikan informasi obat dan pengobatan ([4], dalam hal ini penggunaan produk terkait Covid-19 seperti masker, hand hygiene, desinfeksi, dan suplemen imunitas.

Berdasarkan hal tersebut penting untuk menentukan tingkat pengetahuan mahasiswa farmasi terkait upaya preventif Covid-19 yang berkaitan dengan produk kefarmasian. Berdasarkan penelaahan literatur, studi yang ada menggunakan kuesioner semiterstruktur menitikberatkan pada pengetahuan aspek Covid-19 secara umum bukan penggunaan produk kefarmasian dan alat kesehatan. Studi yang dilakukan pada mahasiswa masih terbatas.

Studi yang dilakukan Al Khawsaneh, dkk pada tahun 2020 di Jordan pada 1404 mahasiswa kesehatan menggunakan kuesioner dengan item pertanyaan meliputi pengetahuan mengenai sumber transmisi dan faktor resiko. Upaya preventif dinilai sebagai tindakan yang dilakukan. Asesmen validitas dan reliabilitas tidak disebutkan.[5]

Studi yang dilakukan Taghrir, dkk. pada tahun 2020 di Iran pada 240 orang mahasiswa menggunakan kuesioner terdiri 15 item hasil adaptasi kuesioner MERS yang valid secara konten dan reliabel dengan koefisien Cronbach's Alpha sebesar 0.80 . Item pertanyaan meliputi : etiologi, diagnosis, transmisi, preventif umum, terapi dan rujukan.[6]

Data hasil survei daring melalui WhatsApp Messenger yang melibatkan 6249 respons mahasiswa 10 universitas di Indonesia. Survei ini menggunakan kuesioner dengan 18 item pengetahuan terutama pada aspek sains dasar dan transmisi. Pada kuesioner ini tidak membahas penggunaan produk kefarmasian dan alat kesehatan. Validitas kuesioner meliputi konten dan muka dengan nilai RMSE nyata 0.98. [7]

Keterbatasan studi baik aspek tema dan subjek berimplikasi pada keterbatasan instrumen yang valid, reliabel dan dapat diterapkan dalam konteks Indonesia. Oleh karena itu, penelitian ini bertujuan untuk menguji validitas dan reliabilitas hasil pengembangan kuesioner gambaran pengetahuan mahasiswa terkait penggunaan produk kefarmasian dan alat kesehatan dalam upaya preventif Covid-19. Kuesioner ini penting disusun untuk memperoleh akurasi alat ukur dan bermanfaat sebagai dasar penyusunan strategi preventif-promotif dalam menghadapi Covid-19.

\section{METODE PENELITIAN}

Penelitian ini merupakan penelitian dengan rancangan deskriptif potong lintang dan berlangsung pada bulan November 2020. Izin kelayakan etik diperoleh dari Komite Etik Fakultas Kedokteran Universitas Mataram (Surat No.
195/UN.18.F7/ETIK/2020). Penelitian ini merupakan bagian dari survei pengetahuan mahasiswa terkait penggunaan produk kefarmasian dan alat kesehatan dalam upaya preventif Covid-19. Tahapan setiap prosedur diilustrasikan dalam Gambar 1.

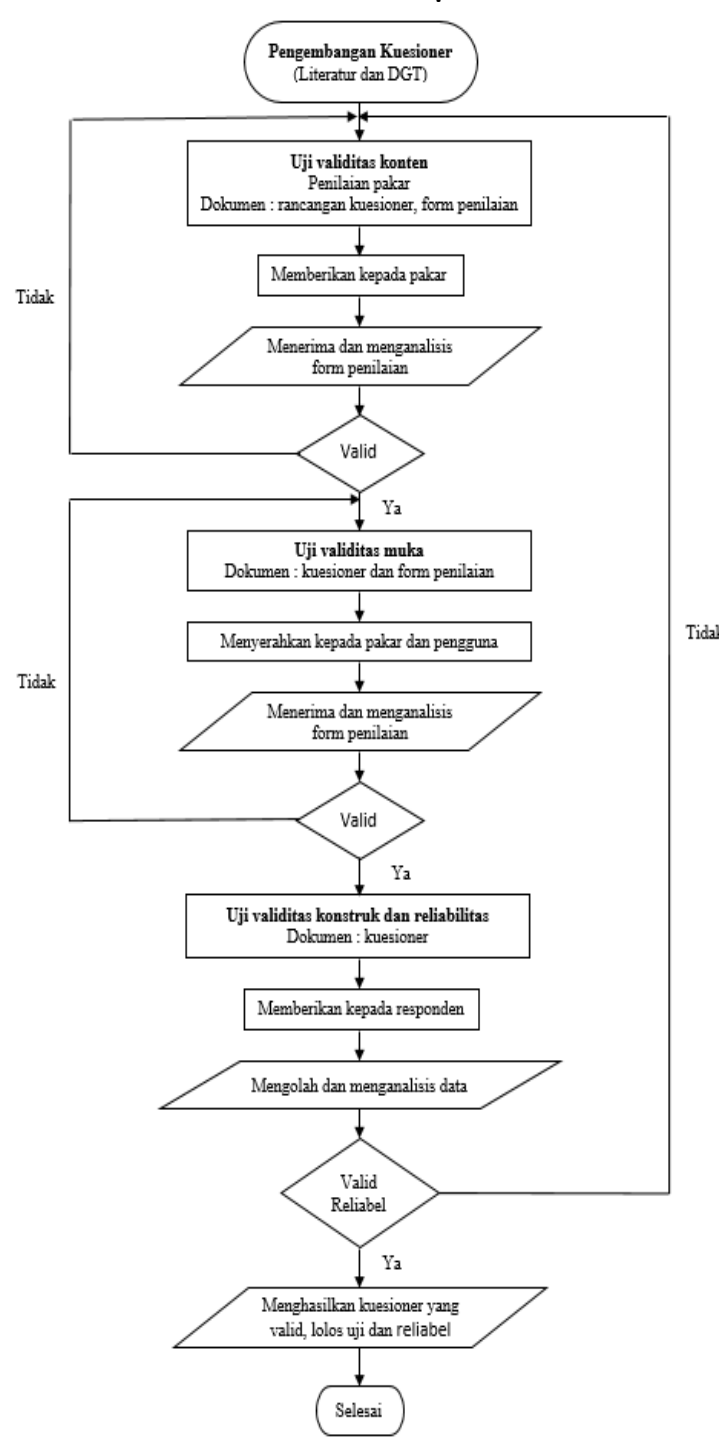

Gambar 1. Alur penelitian

\section{Pengembangan item pernyataan via studi literatur}

Konseptualisasi serta desain kuesioner dilakukan melalui kajian literatur berdasarkan panduan $[8,1,10,11,12,14,15,16]$. Tahapan yang dilakukan meliputi: identifikasi domain, penyusunan item pernyataan dan pembentukan kuesioner.

Draf awal kuesioner tersusun atas 4 bagian (54 pertanyaan) meliputi: (a) penggunaan masker-19 butir, (b) hand hygiene-12 butir (c) pengunaan desinfektan 9 butir, dan (d) penggunaan suplemen imunitas-14 butir.. Jawaban terdiri 4 opsi (benar, salah, ragu-ragu dan tidak tahu). 


\section{Pengembangan item pernyataan via Diskusi Grup Terarah (DGT) \\ DGT dilakukan secara daring dengan} melibatkan 2 kelompok terdiri atas 8 mahasiswa dan 3 praktisi. dipandu masing-masing seorang fasilitator dan notulen. DGT berlangsung hingga jenuh dan berakhir setelah 60 menit.

Diskusi dimulai dengan ilustrasi kasus dilanjutkan dengan pertanyaan terbuka secara terstruktur. Hasil DGT ditranskripsi lalu dianalisa secara kualitatif. Penambahan satu item dan penggabungan dua item sehingga total keseluruhan item pernyataan kuesioner sejumlah 55 buah.

\section{Uji validitas konten}

Uji validitas konten bertujuan untuk sejauh mana isi tes sesuai dengan tujuan [16]. Uji inidilakukan secara kualitatif dan kuantitatif menggunakan penilaian 6 pakar (keahlian kesehatan masyarakat, farmasi praktis dan bahan alam.) Kuesioner dinyatakan valid apabila diperoleh persetujuan antar pakar secara kualitatif dan nilai CVR> 0.99 sesuai tabel Lawshe serta ICV-I $\geq 0,79$ secara kuantitatif [17].

\section{Uji validitas muka}

Uji validitas muka bertujuan untuk menilai pemahaman bahasa yang digunakan, tampilan dan tata letak kuesioner. Uji ini menyertakan 7 orang mahasiswa secara daring sebagai pengguna. Kuesioner dinyatakan valid hingga diperoleh hasil bahasa kuesioner telah dipahami, tata letak dan alur dapat diterima oleh responden [18].

\section{Uji validitas konstruk}

Uji validitas konstruk bertujuan untuk menilai item-item pertanyaan dalam kuesioner mampu mengukur apa yang benar diukur sesuai dengan konsep khusus yang telah ditetapkan. Uji reliabilitas ini menyertakan 30 orang mahasiswa sebagai responden. Setelah pemeriksaan kelengkapan data, skor isian dianalisa dengan menggunakan uji korelasi bivariat Pearson. Item pertanyaan valid bila koefisien hitung lebih besar dari tabel [19].

\section{Uji reliabilitas}

Uji reliabilitas bertujuan untuk menilai apakah kuesioner dapat memberikan hasil ukur yang sama. Uji ini menyertakan 30 orang mahasiswa dari berbagai angkatan sebagai pengguna. Setelah pemeriksaan kelengkapan data, skor isian dianalisa dengan menggunakan uji reliabilitas Alpha Cronbach's. Nilai koefisien di atas 0,70 menunjukkan item pertanyaan memiliki reliabilitas yang baik. [20].

\section{HASIL DAN PEMBAHASAN Validitas isi}

Pada uji validitas secara kualitatif, tidak terdapat penambahan atau pengurangan item.
Perbaikan pemilihan kata dan parafrase dalam item pertanyaan dilakukan untuk menghindarkan ambiguitas sesuai dengan saran dari panel pakar.

Secara kuantitatif, diperoleh nilai I-CVI untuk tiap item pertanyaan sebesar 1 , kecuali dari salah seorang pakar untuk item pertanyaan no. 2 (nilai relevansi $=2$ ) terkait penggunaan masker boleh digunakan pada bayi diperoleh nilai I-CVI sebesar 0,8. Oleh karenanya 55 item yang diajukan dinyatakan valid (nilai ICV-I > 0,79) sebagaimana diilustrasikan dalam Tabel 1 [21]

Tabel 1. Nilai Indeks Validitas Konten (ICV-I)

\begin{tabular}{ccccc}
\hline Item & $\begin{array}{c}\text { Relevan } \\
(\mathbf{3 - 4})\end{array}$ & $\begin{array}{c}\text { Tak } \\
\text { Relevan } \\
(\mathbf{1 - 2})\end{array}$ & I-CVI & $\begin{array}{c}\text { Simpul } \\
\text { an }\end{array}$ \\
\hline $\begin{array}{c}\text { ABCD } \\
(54\end{array}$ & 5 & 0 & 1 & Layak \\
$\begin{array}{c}\text { item }) \\
\text { A2 }\end{array}$ & 4 & 1 & 0.8 & Layak \\
\hline
\end{tabular}

CVI terdiri atas : I-CVI, S-CVI (SCVI/Ave dan S-CVI/UA) yang mengukur keseluruhan skala [22]. S-CVI/Ave merupakan rerata skor I-CVI seluruh item pada skala sementara S-CVI/UA merupakan perbandingan jumlah UA terhadap seluruh item [23].

Pustaka lain menganjurkan suatu item valid menyertakan kedua indeks ini selain I-CVI. Nilai S-CVI/UA dan S-CVI/Ave berturut-turut sebesar 0,8 dan 0,9 atau klebih tinggi pada item maka dinyatakan valid [24]. Nilai S-CVI/Ave dan S-CVI/UA sebesar 0,996 mendukung nilai ICVI dan menunjukkan validitas kuesioner.

Adapun nilai CVR secara umum pada masing-masing item bernilai 1 kecuali item no. 11 sebagaimana pada Tabel 2. Pernyataan ketika melepas masker dimulai dengan menyentuh tangan bagian depan memiliki nilai CVR sebesar 0.6 (dinilai esensial oleh 4 dari 5 pakar). Nilai tersebut lebih kecil dibandingkan Tabel Lawshe $(\mathrm{CVR}<0.99)$ sehingga pernyataan dihapus [25].

Tabel 2. Nilai Rasio Validitas Konten (CVR)

\begin{tabular}{cccc}
\hline Item & $\begin{array}{c}\text { Nilai } \\
\text { Esensial }\end{array}$ & CVR & Simpulan \\
\hline $\begin{array}{c}\text { ABCD } \\
(54\end{array}$ & 5 & 1 & Dipertahankan \\
item $)$ & & & \\
A11 & 4 & 0.6 & Dibuang \\
\hline
\end{tabular}

Nilai CVR menggambarkan validitas item secara individual. Nilai ini dihitung untuk menspesifikasikan apakah item soal penting untuk mengoperasikan konstruk yang diberikan [26,27]. Nilai mendekati positif 1 menunjukkan kesepakatan bersama terhadap item dimaksud, dan tidak diperoleh nilai item negatif [28]. Revisi 
item diberikan kembali kepada pakar. Berdasarkan uji diperoleh pada uji sesi pertama jumlah akhir item pertanyaan sebanyak 54 item.

\section{Validitas muka}

Perbaikan perlu dilakukan pada pernyataan item berupa tumpang tindih kata dalam pernyataan $14,28 \%$ (1 dari 7 putaran). Struktur kuesioner telah dinilai baik oleh keseluruhan responden pada nilai 2 dan 3 meliputi aspek penomoran, alur kuesioner, susunan logis dan pengelompokan pernyataan.

Pada aspek format atau desain visual terdapat koreksi sebesar 28,57 \% (2 dari 7 responden menjawab nilai 1) pada warna dalam kuesioner yang belum kontras. Selain itu terdapat tambahan berupa perbaikan tata tulis dan pengkajian kembali jumlah item yang dirasa terlalu banyak oleh 1 responden.

Perbaikan dilakukan pada beberapa item pertanyaan hingga mudah dipahami oleh responden. Misal pada pertanyaan no. 9 : 'Lama cuci tangan dilakukan minimal maksimal 20 detik' diganti dengan 'Cuci tangan dilakukan selama minimal 20 detik'. Hasil perbaikan dinyatakan cukup via WhatsApp Messenger oleh 7 responden

\section{Validitas konstruk dan reliabilitas}

Karakteristik demografis responden adalah $20 \%$ mahasiswa dan $80 \%$ mahasiswi dengan lama kuliah 4,5-5 tahun. Seluruh responden pernah menggunakan produk farmasi dan alat kesehatan sebelumnya. Akses informasi terbanyak berasal dari media elektronik $(83,33 \%)$ sementara lainnya berasal dari media sosial (16.67\%), Waktu yang dibutuhkan mengisi oleh responden sekitar 10-20 menit.

Hasil uji reliabilitas pada 30 orang responden memberikan nilai 0.881 . Jumlah 30 cukup untuk memperoleh ukuran efek yang diharapkan 0,7 [29] Nilai lebih besar dari 0.7 menunjukkan item reliabel [30]. Nilai korelasi total -item terkoreksi pada 14 pertanyaan kurang dari 0,3. sehingga dinyatakan tidak valid atau dibuang. Total item yang valid dan reliabel diperoleh 40 item (dengan nilai korelasi total item terkoreksi 0,308-1). Beberapa pernyataan dalam kuesioner diilustrasikan pada Tabel 3.

Tabel 3. Ilustrasi Pernyataan Kuesioner

\begin{tabular}{cl}
\hline No & \multicolumn{1}{c}{ Butir Pernyataan } \\
\hline 1 & $\begin{array}{l}\text { Satu masker hanya digunakan oleh satu } \\
\text { orang }\end{array}$ \\
2 & $\begin{array}{l}\text { Sebelum dan sesudah menggunakan } \\
\text { masker harus mencuci tangan terlebih } \\
\text { dahulu }\end{array}$ \\
3 & $\begin{array}{l}\text { Bagian masker yang berwarna pada } \\
\text { masker medis digunakan pada luar muka }\end{array}$ \\
4 & $\begin{array}{l}\text { Produk handsanitizer dapat digunakan } \\
\text { ketika tidak ada air dan sabun } \\
\text { Produk handsanitizer dapat membunuh } \\
\text { semua kuman }\end{array}$ \\
\hline
\end{tabular}

\begin{tabular}{clc}
\hline No & \multicolumn{3}{c}{ Butir Pernyataan } \\
\hline 6 & $\begin{array}{l}\text { Keran air dapat ditutup dengan } \\
\text { menggunakan siku setelah selesai } \\
\text { mencuci tangan }\end{array}$ \\
7 & $\begin{array}{l}\text { Permukaan yang kotor harus dibersihkan } \\
\text { dengan air dan sabun sebelum desinfeksi }\end{array}$ \\
8 & $\begin{array}{l}\text { Jumlah dan lama kontak desinfektan } \\
\text { tidak berpengaruh terhadap keberhasilan } \\
\text { desinfeksi }\end{array}$ \\
9 & $\begin{array}{l}\text { Setelah desinfeksi dan melepaskan alat } \\
\text { pelindung diri maka seseorang harus } \\
\text { mencuci tangan dengan air dan sabun }\end{array}$ \\
10 & $\begin{array}{l}\text { Vitamin C dapat diminum 500 mg tiga } \\
\text { kali sehari untuk memelihara imunitas } \\
\text { tubuh dalam menghadapi COVID-19. }\end{array}$ \\
11 & $\begin{array}{l}\text { Vitamin C sebaiknya diberikan pada } \\
\text { wanita hamil dan menyusui } \\
\text { Obat tradisional yang baik dapat } \\
\text { diperoleh secara offline dan online }\end{array}$ \\
\hline
\end{tabular}

\section{KESIMPULAN}

Sejumlah 40 item pernyataan dalam kuesioner gambaran pengetahuan pengetahuan mahasiswa terkait penggunaan produk kefarmasian dan alat kesehatan dalam upaya preventif Covid-19 dinyatakan valid dan reliabel berdasarkan parameter validitas dan reliabilitas.

\section{DAFTAR PUSTAKA}

[1] Pariang, N. F. E., Ellen, W., Prih, S., Zullies, I., Retnosari, A., Ika, P., Lusy, N. (2020). Panduan Praktis Apoteker Menghadapai Pandemi Covid -19. Jakarta : PT. ISFI Penerbitan.

[2] Dinas Kesehatan Provinsi NTB. (2020). Pemerintah Serius, Siap dan Mampu Menangani COVID-19 Masyarakat Tetap Tenang\&Waspada. (Update terakhir tanggal 21 November 2020).

[3] Kementerian Pendidikan dan Kebudayaan. (2020). Tekan Laju COVID-19, Kemendikbud Bekali Mahasiswa Duta Perubahan Perilaku Masyarakat

[4] Asosiasi Pendidikan Tinggi Farmasi Indonesia, (2013). Naskah Akademik Standar Kompetensi Lulusan dan Standar Kurikulum Pendidikan Farmasi.

[5] Khawsaneh, A. I., Humedian, A. A., Alsulaiman, J. W., Bloukh, S., Ramadan, M., Al-Shatanawi, T. N., Awad, H. H., Hijazi, W. Y., Al-Kammash, K. R., Obeidat, N., Saleh, T. and Kheirallah, K. A. (2020). Medical Students and COVID-19: Knowledge, Attitudes, and Precautionary Measures. A Descriptive Study From Jordan. Front Public Health. 8 (253). 1-9.

[6] Taghrir, M. H., Borazjani, R., and Shiraly, R. (2020). COVID-19 and Iranian Medical Students; A Survey on Their relatedknowledge, Preventive Behaviors and Risk 
Perception. Archive Iranian Medicine. 23 (4) : 249-254

[7] Saefi, M., Fauzi, A., Kristiana, E., Adi, W. C., Muchson, M., Setiawan, M. E., Islami, N. N., Ningrum, D. E. A. A., Ikhsan, M. A and Ramadhani, M. (2020). Survey Data of Covid19-related Knowledge, Attitude, and Practice among Indonesian undergraduate students. Data in Brief Elsevier. 31: 1-10.

[8] World Health Organization. (2020). Anjuran mengenai penggunaan masker dalam konteks COVID-19. Panduan interim 5 Juni 2020.

[9] Center of Disease Control. (2020). Cleaning And Disinfecting Your Home Everyday Steps and Extra Steps When Someone Is Sick.

[10]Center of Disease Control. $\left(2020^{\mathrm{b}}\right)$. Considerations for Wearing Masks Help Slow the Spread of COVID-19.

[11]Center of Disease Control. $\left(2020^{c}\right)$. Hand Hygiene Recommendations Guidance for Healthcare Providers about Hand Hygiene.

[12] Kementerian Kesehatan. (2020). Panduan Menjaga Kebersihan Lingkungan dan Langkah - Langkah Disinfektan Dalam Rangka Pencegahan Penularan Covid-19. Kementerian Kesehatan. Jakarta

[13] Badan Pengawas Obat dan Makanan. (2020). Informasi Obat Modern Asli Indonesia (OMAI) di Masa Pandemi Covid-19. Badan Pengawas Obat dan Makanan, Jakarta

[14] Badan Pengawas Obat dan Makanan. (2020 $)$. Pedoman Penggunaan Herbal dan Suplemen Kesehatan dalam Menghadapi Covid-19 di Indonesia. Badan Pengawas Obat dan Makanan, Jakarta

[15] Badan Pengawas Obat dan Makanan. (2020). Buku Saku "Obat Tradisional untuk Daya Tahan Tubuh. Badan Pengawas Obat dan Makanan, Jakarta

[16] Hendryadi. (2017). Validitas Isi: Tahap Awal Pengembangan Kuesioner. Jurnal Riset Manajemen dan Bisnis (JRMB) Fakultas Ekonomi UNIAT, 2 (2), 169-178.

[17]Zamanzadeh, V., Ghahramanian, Rassouli, M., Abbaszadeh, A., Alavi-Majd, H., and Nikanfar, A., (2015). Design and implementation content validity study: Development of an instrument for measuring patient centered communication. Journal of Caring Sciences, 4(2), 165-178.

[18] Kumari, A., Ranjan, P., Vikram, N. K., Kaur, D., Sahu, A., Dwivedi, S. N., Baitha, U. and Goel, A. (2020). COVID-19 A short questionnaire to assess changes in lifestyle-related behaviour during COVID 19 pandemic. Diabetes Metabolic Syndrome. 14 (6), 1679-1701
[19] Sani K,F. (2018). Metodologi Penelitian Farmasi Komunitas dan Eksperimental. Yogyakarta: Deepublish.

[20] Bolarinwa, O. A., (2015). Principles and methods of validity and reliability testing of questionnaires used in social and health science researches. Nigerian Postgraduate Medical Journal 22(4), 195-201

[21] Rodrigues, I. B., Adachi, J. D., Beattie, K. A., and MacDermid, J. C. (2017). Development and validation of a new tool to measure the facilitators, barriers, and preferences to exercise in people with osteoporosis. BMC Musculoskeletal Disorders. 18 (540) : 1-9

[22] Polit, D. F. and Beck, C. D, (2006). The content validity index: Are you sure know what's being reported ? critique and recommendations. Research in Nursing \& Health, 29(5) 489-497

[23] Yusoff, M. S. B. (2019) ABC of Content Validation and Content Validity Index Calculation. Educational Resource, 11 (2) : 49-54

[24] Shi, J., Mo, X., Sun, Z., (2012) Content validity index in scale development. Journal of Central South University Medical Sciences, 37 (2) : 152-155

[25]Zerati, M. and Alavi, N. (2014). Designing and Validity Evaluation of Quality of Nursing Care Scale in Intensive Care Units. Journal of Nursing Measurement , 22(3), 461-71

[26] Gilbert, G.E. and Prion, S. (2016). Making Sense of Methods and Measurements: Lawshe's Content and Validity Index. Clinical Simulation in Nursing, 12, 530-531

[27] Shrotyria, V. K. and Dhanda, U. (2019). Content Validity of Assesment Instrument for Employee Engagement. SAGE Open, 2019, 1-7

[28] binti Ramli, N. F., bin Talib, O., binti Abdul Manaf, U. K., Hassan , S. A, Content Validity of STEMTIP. International Journal of Academic Research in Business and Social Sciences. 8(7), 1119-1125

[29]Bujang, M. A., Omar, E. D., and Baharum, N. A., (2018), A Review on Sample Size Determination for Cronbach's Alpha Test : A Simple Guide for Researchers. Malaysian of Journal Medical Science 25(6): 85-99

[30] Taber, K. S., (2017). The Use of Cronbach's Alpha When Developing and Reporting Research Instruments in Science Education. Research Science Education ,48: 1273-1296 